\title{
The Youth Empowerment Project: Strengthening NGO Management, Research and Service Delivery Capabilities in Botswana
}

Mercy Rapelesega

Naomi Rutenberg

Population Council

Follow this and additional works at: https://knowledgecommons.popcouncil.org/departments_sbsr-rh

Part of the International Public Health Commons, and the Public Health Education and Promotion Commons

How does access to this work benefit you? Let us know!

\section{Recommended Citation}

Rapelesega, Mercy and Naomi Rutenberg. 1997. "The Youth Empowerment Project: Strengthening NGO Management, Research and Service Delivery Capabilities in Botswana," final report. Nairobi: Population Council. 
September 1997

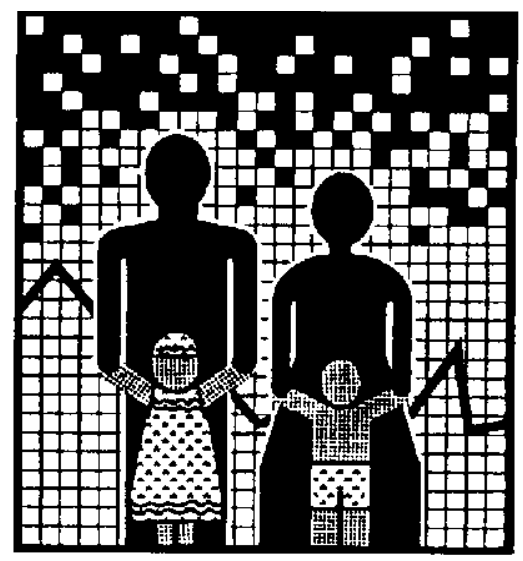

OPERATIONS

RESEARCH

TECHNICAL ASSISTANCE

AFRICA PROJECT II

THE POPULATION COUNCIL

\section{The Youth Empowerment Project}

Strengthening NGO Management, Research and Service

Delivery Capabilities in Botswana 



\section{The Population Council}

The Population Council seeks to help improve the well-being and reproductive health of current and future generations around the world and to help achieve a humane, equitable, and sustainable balance between people and resources. The Council analyses population issues and trends; conducts biomedical research to develop new contraceptives; works with public and private agencies to improve the quality and outreach of family planning and reproductive health services; helps governments to influence demographic behavior, communicates the results of research in the population field to appropriate audiences; and helps build research capacities in developing countries. The Council, a nonprofit, nongovernmental research organization established in 1952, has a multinational Board of Trustees; its New York headquarters supports a global network of regional and country offices.

\section{Africa OR/TA Project 11}

The overall objective of the Africa OR/TA Project II is to broaden understanding of how to improve family planning services in Sub-Saharan Africa, and to apply operations researchand technical assistance to improve services by:

- increasing access to a full range of family planning services and methods;

- developing service delivery strategies that are client-oriented and acceptable to various population groups;

- improving the operations of programs to make them more efficient and financially sustainable;

- improving the quality of services;

- strengthening the capabilities of family planning program managers to use operations research to diagnose and solve service delivery problems.

This project was supported by the Population Council's Operations Research and Technical Assistance Project II, Project No. 936-3030, and by the Population Council's Cooperative Agreement No. CCP-3050-A-00-4013-00, both funded by the United States Agency for International Development (USAID). 



\section{ACKNOWLEDGMENTS}

This report has drawn on the experiences of the eleven NG0s, the Population Council, the Botswana National Productivity Centre (BNPC), the Ministry of Health Research Unit (HRU), and the National Institute of Research, Sociology Department and Faculty of Environmental Science of the University of Botswana who formed the Youth Empowerment Project implementing team. We particularly would like to acknowledge Bernard Pakes of the BNPC and Pilate Khulumani who led the BNPC and HRU teams, respectively, and prepared the final project reports, and the many NGO staff who provided feedback on the knowledge and skills acquired through their participation in the Youth Empowerment Project. In addition, we would like to thank our colleagues in the Africa OR/TA project and Sefale Montsi for reviewing draft reports and Scott Stewart and colleagues from USAID/Botswana for their assistance throughout in implementing the project. 


\section{TABLE OF CONTENTS}

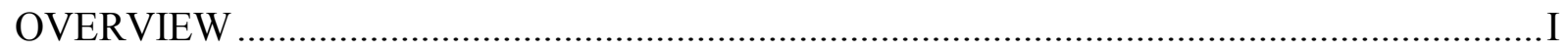

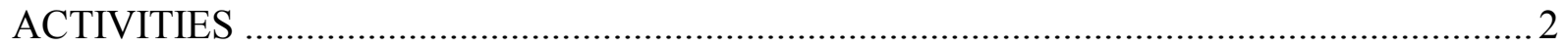

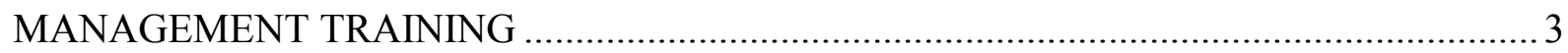

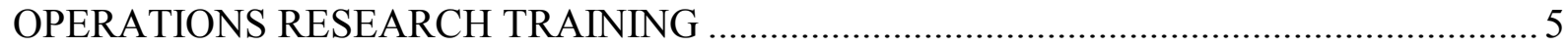

CREATION OF NGO DATABASE AND GEOGRAPHIC INFORMATION SYSTEM ........ 7

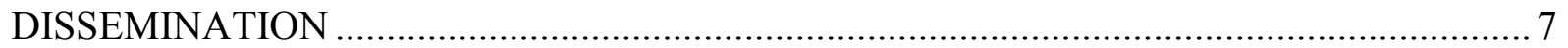

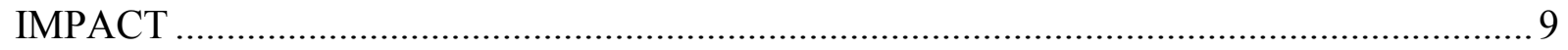

LESSONS LEARNED ABOUT NGO STRENGTHENING .............................................. 16

Design factors which contributed to the success of the project............................................ 16

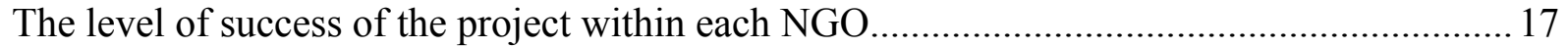

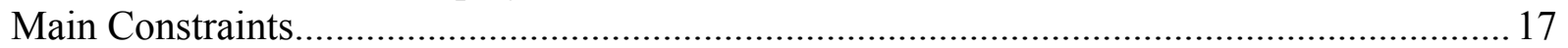

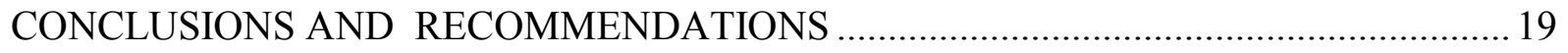

SPECIFIC RECOMMENDATIONS FROM THE PARTICIPANTS .................................. 20 


\section{OVERVIEW}

In an expansion of its efforts to fight a growing HIV epidemic and high teenage pregnancy rates, the Government of Botswana is encouraging non-governmental organizations (NG0s) to be more active in providing reproductive health services, and especially HIV/AIDS education and care, to adolescents. NG0s have the potential to assume a larger role as health and education providers as well as implement pilot projects which the public health sector could learn from to increase the availability and quality of reproductive health services for youth. The Africa OR/TA Project 11 designed and implemented the Youth Empowerment Project (YEP) to assist youth-oriented NG0s to take on greater responsibility for adolescent reproductive health and education in Botswana. The YEP was part of USAID's Botswana Population Sector Assistance Project which assisted the Government of Botswana to improve the accessibility and effectiveness of reproductive health care provided by the public and NGO sectors.

The Youth Empowerment Project focused on strengthening the management and service delivery capabilities of the participating NG0s. YEP followed a two-pronged strategy for NGO strengthening:

a local parastatal management training and consulting organization, the Botswana National Productivity Centre (BNPC), assisted the NG0s to identify and address organizational and managerial issues,

and the Health Research Unit (HRU) of the Ministry of Health provided training and technical assistance to the NG0s in how to use operations research to improve the delivery of reproductive health services.

The BNPC housed the project coordinating office, served as the training venue, provided the main financial management service and the technical assistance and management training while the HRU provided the training and technical assistance on health system,; research. Eleven NG0s participated in the Youth Empowerment Project which ran from October 1995 to September 1996. 


\section{ACTIVITIES}

Project activities were initiated with a Project Kick-off Workshop in November 1995 where the Africa OR/TA Project 11, BNPC, and the HRU introduced the project to interested NG0s and confirmed their commitment, participation and involvement in its implementation. The kick-off workshop also provided an opportunity to collect information on each NGO which was used to establish a baseline for the NG0s participating in the project. At this workshop, the participants selected the name "Youth Empowerment Project" for the project. The eleven NG0s who chose to participate in YEP were varied in structure, size, and objectives. They included:

National, youth oriented NG0s linked with international networks (Botswana Scouts Association, Girl Guides, and the Young Women Christian's Association),

an autonomous, indigenous youth oriented NGO (The Botswana Youth Centre),

NG0s with a reproductive health but not necessarily a youth focus (Botswana

Family Welfare Association - the IPPF affiliate in Botswana - and Population Services International),

NG0s with mandates relating to community development, health, and education (The Red Cross, Association of Medical Missions in Botswana, AIDS Action Trust, and Mambo Arts Commune), and

the NGO established in Botswana to serve as a clearinghouse of information and central network point for all NGO activities (BOCONGO).

Eleven NGOS participated in the management development activities and eight NG0s attended the operations research training and participated in the operations research studies. 


\section{MANAGEMENT TRAINING}

The initial program of activities under the management component of YEP was a series of individualized retreats facilitated by the BNPC where a core of representative staff from each NGO used a participatory methodology to assess which characteristics of the NGO had the potential to affect individual and/or organizational performance. The retreats were followed by a program of four management workshops: Strategic Management Workshop; Change Management and Time Management; Performance Management; and Project Management. These management workshops addressed the training needs identified through the kick-off workshops and retreats.

The final set of management strengthening activities was the delivery of technical assistance by BNPC to individual NG0s to enhance performance. The following examples of technical assistance show some of the various needs of the NG0s for institutional development:

The Botswana Red Cross Society management identified and acknowledged factors which inhibited effective communication between service personnel and management and among the various programs, acknowledged the need to address these as a matter of priority, and committed itself to take action.

The Botswana Family Welfare Association worked on volunteer motivation, performance management (staff appraisal, development and improvement of work environment), impact measurement, fund raising, and income generation. 


\begin{tabular}{|c|c|c|}
\hline Workshop Theme & Purpose & Main Topics \\
\hline $\begin{array}{l}\text { Strategic } \\
\text { Management }\end{array}$ & $\begin{array}{l}\text { Develop long range plans. } \\
\text { Participants learned about the } \\
\text { strategic planning process and } \\
\text { acquired hands-on skills in } \\
\text { preparation for developing or } \\
\text { revising NGO -specific long range } \\
\text { plans. }\end{array}$ & $\begin{array}{l}\text { - Strategic management } \\
\text { and its context } \\
\text { - Strategic management } \\
\text { concepts } \\
\text { - Strategic management } \\
\text { thinking and analysis } \\
\text { tools }\end{array}$ \\
\hline $\begin{array}{l}\text { Change } \\
\text { Management and } \\
\text { Time Management }\end{array}$ & $\begin{array}{l}\text { Familiarize NGO representatives } \\
\text { with the process of change } \\
\text { management and impart skills to } \\
\text { manage change and time more } \\
\text { effectively. }\end{array}$ & $\begin{array}{l}\text { - The reality of change } \\
\text { - The process of change } \\
\text { - Time management }\end{array}$ \\
\hline $\begin{array}{l}\text { Performance } \\
\text { Management }\end{array}$ & $\begin{array}{l}\text { To assist NGO representatives to } \\
\text { become effective in important } \\
\text { aspects of performance } \\
\text { management. Participants were } \\
\text { introduced to a range of } \\
\text { performance management tools and } \\
\text { techniques which participants could } \\
\text { use to manage their own } \\
\text { performance as well as that of } \\
\text { others. }\end{array}$ & $\begin{array}{l}\text { - Performance } \\
\text { management and its } \\
\text { context } \\
\text { - Performance } \\
\text { management practices } \\
\text { - Performance } \\
\text { management enablers }\end{array}$ \\
\hline $\begin{array}{l}\text { Project } \\
\text { Management }\end{array}$ & $\begin{array}{l}\text { To become effective in key aspects } \\
\text { of project management. Participants } \\
\text { were introduced to the cycle of } \\
\text { project management and acquired } \\
\text { skills to enhance their effectiveness } \\
\text { in the delivery of project } \\
\text { management performance. }\end{array}$ & $\begin{array}{l}\text { - Project management and } \\
\text { its context } \\
\text { - Project management } \\
\text { practices }\end{array}$ \\
\hline
\end{tabular}




\section{OPERATIONS RESEARCH TRAINING}

The Health Research Unit coordinated a parallel set of strengthening activities in which staff from eight NG0s received training on how to use and design operations research to increase NGO performance. The NG0s formed teams, each with a facilitator from the HRU, and prepared four research proposals. Africa OR/TA Project 11 staff worked closely with the staff from the participating NG0s to revise the proposals and eventually all were approved for funding. These were small scale studies which entailed a few weeks of fieldwork and cost between three and eight thousand dollars. After completing data collection, the research teams brought their data to a second training workshop which focused on data analysis, report writing, and preparation for dissemination of the results to the managers of their respective NG0s. 


\section{Overview of Operations Research Training}

\begin{tabular}{|c|}
\hline Step One: \\
Identifying Short List of Research \\
Topics - Participants in the research \\
training conferred with their \\
organisations and drew up a short-list of \\
three possible problem areas from which \\
to select and develop research topics. \\
\hline
\end{tabular}

\section{Step Four:}

Data Analysis and Report Writing Data analysis and report writing were conducted through a 13-day intensive workshop during which participants developed the outline for their reports and prepared summaries for oral dissemination of the results.

\begin{tabular}{|c|} 
Step Five: \\
Dissemination of Research Findings - \\
Participants developed slides of main \\
findings and recommendations for an in- \\
house mini-dissemination for the \\
management staff of their NG0s. The \\
main objective of this activity was to \\
enable the NGO management to receive, \\
discuss and use the results to make \\
specific management decisions in line \\
with the main objectives of the study \\
they had approved. The main research \\
findings and recommendations were then \\
presented at a one day final \\
dissemination workshop at the end of the \\
project.
\end{tabular}

\section{Step Two:}

Problem Identification and Proposal Development Workshop - Seventeen days of classroom work that covered both the theory of health systems research and practical application: identification of researchable problem areas, definition of a research topic for each team and step by step development of a detailed, budgeted research proposal.

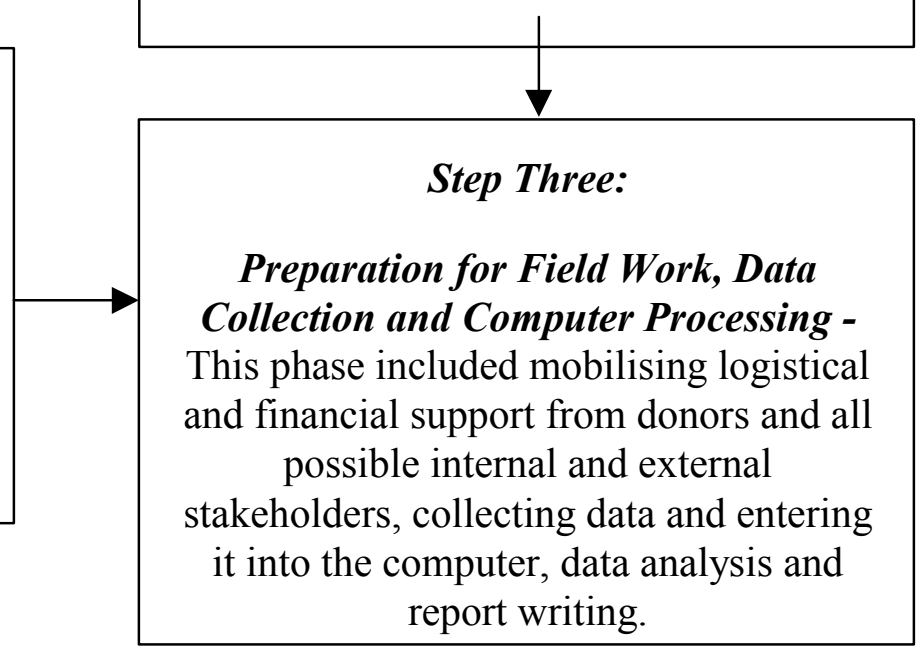

report writing.

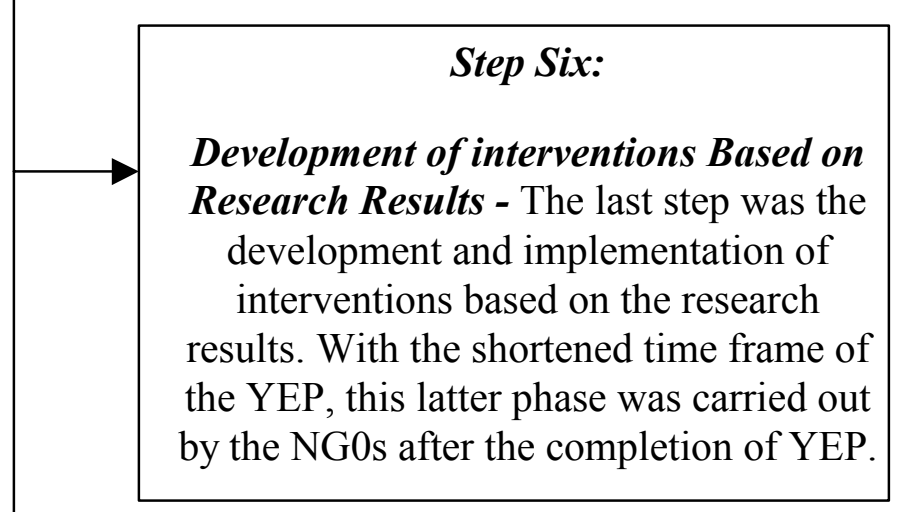


CREATION OF NGO DATABASE AND GEOGRAPHIC INFORMATION SYSTEM

An activity not originally anticipated under the YEP project was the establishment of a centralized database and geographic information system on NGO activities in Botswana. The kick-off workshop revealed a need for such a database to facilitate collaboration and networking as well as to provide access to information about NG0s to government and donor agencies. By the end of the project period, the Botswana Council of NG0s had completed a database with information on most NG0s in the country as well as attractive, colorful maps showing the locale and type of activity for the YEP NG0s and registered members of the Botswana Council of NG0s. The maps were in use even before the completion of the project with one NGO taking its map to an overseas international conference where it notably increased recognition of the NGO.

\section{DISSEMINATION}

The final project workshop in September, 1996 was used as a platform for participating NG0s to share their experiences and begin to mobilize further support (both technical and financial) from the government, the private sector and the international donor community to sustain and continue to improve on the gains made through the project. The workshop was attended by early 80 participants from various government sectors, donors, the university, and the private sector., An ad hoc committee composed of members of NG0s who participated in YEP presented recommendations for follow-up action. The First Lady, Lady Masire, was an active participant at this workshop both because of her experience in the project as the Executive Director of the Botswana Youth Centre and as a member of the ad hoc committee.

The principal recommendation of the committee, which was endorsed by the workshop participants, was to solicit BNPC and HRU technical support beyond the life of Y-EP in order to gain more experience in applying the information, knowledge, and skills acquired from the YEP project as well as to utilize the results of the research projects for improving and revising their programs. They recommended that a second phase include a "training of trainers" so that the management training could be more widely shared within each NGO and thus create a common approach and supportive environment to the application of new management techniques. 
The external stakeholders (government, the private sector, donors, etc.) who attended the final dissemination workshop confirmed the important role of NG0s in youth reproductive health in Botswana and stressed the need for a collective approach for resources mobilization. They also provided guidance on sources of support and, in some cases, offered specific financial, logistical or other support. For example:

- The Director of the Department of Youth and Sports mentioned that, subject to appropriate communication and planning, the Department could benefit from the operations research capability of NG0s by commissioning and funding research on youth issues by NG0s as part of the implementation of the new national youth policy.

- The Ministry of Finance and Development Planning confirmed the potential for finding NGO training in population issues especially in youth reproductive health management.

- Participants from the private sector and UN agencies (UNFPA and UNICEF) expressed particular interest in continuing collaboration in various aspects of the NGO youth reproductive health activities.

- The BYC, one of the YEP NG0s, merged with the Botswana National Youth Council which is fully funded by the government to build a youth center. BYC has a large piece of land and construction plans for a youth center while the Council has assured government funding for construction and for running programs. UNICEF will also provide some funding to include construction of a youth health clinic at the Botswana Youth Centre. 


\section{IMPACT}

The YEP project was originally conceived to last 18 months but had to be implemented in less than 10 months due to delays in the start of the project. ${ }^{1}$ Nonetheless all planned project activities were completed and all four project objectives achieved to a significant extent considering the time frame. The training and technical assistance programs were taken advantage of by most of the participating NG0s who acquired and applied basic knowledge and skills in performance management to strengthen different aspects of their management and service delivery systems. The technical assistance program enabled each NGO to focus on special areas of priority needs. Upon the conclusion of the project, NGO participants made some of the following observations:

"The workshops were an eye opener to the majority of the participants. The training enabled us to step back and make an objective and critical analysis of our difficulties as well as solutions and options. The YEP courses prepared participants to recognize the need for change, accept change, and provided skills to initiate change in the management of our NGOs."

"The research skills provided ably complements the management training modules. Of particular significance is the principle that management decisions must be based on objective data and information and that there must be a continuous flow of such information through the management systems."

Specific examples of the impact of the project under each project objective are given below.

\section{Objective One: To provide general management training and tailor-made technical assistance to NG0s who are active in reproductive health in program planning, development, implementation, evaluation and communication and dissemination.}

- Mambo Arts Commune worked on project proposal development and project management and identification of training needs and resources. The NGO used its newly acquired 
skills to 1) revise a number of research proposals which had been outstanding and submit them for funding with some of them being approved for finding, and 2) train all project leaders in project management so that each of them can take full responsibility of their programs from project proposal writing, resource mobilization and project implementation.

- The Association of Medical Missions for Botswana (AMMIB) learnt to use needs assessment tools as the first step towards the development of an enhanced performance management system.

- Population Services International increased computer literacy among their staff after identifying a deficiency in this area based on the management tools learned in the workshops.

- Many of the NG0s (BSA, ACT, PSI, AMMB) reported that they used the time management training to streamline the day to day running of their offices.

\section{Objective Two: To assist NGOs with developing long range program strategies which are realistic, feasible and cost-effective}

Although it is too early to make judgements on realism, feasibility and cost-effectiveness, several NG0s revised, developed or anticipated creating strategic plans on the basis of the management training and research results:

- The AIDS Action Trust used the technical assistance to introduce a planning retreat at which a three-year strategic plan was produced

- The Boy Scouts Association revised its strategic plan and started on specific activities and consultations to strengthen the youth reproductive health component of the plan and develop specific operational activities in this area

- The Botswana Girl Guides Association, the YWCA and the Botswana Youth Centre used the project to raise awareness among their senior management personnel on the importance of strategic management planning and to strengthen and/or begin work on the development of strategic management plans; 
Objective Three: To provide training to $\mathrm{NGOs}$ who are active in reproductive health in service delivery problem identification and OR proposal development

Twenty-one staff of eight NG0s were trained in service level problem identification and proposal writing. Because the NG0s lacked information about the strengths and weaknesses of their ongoing programs, all of the NG0s chose to carry out diagnostic rather than intervention studies.

Objective Four: To assist selected NGOs with the design, implementation and evaluation of small scale, pilot service delivery projects

Four diagnostic OR studies were completed and used to improve programs and develop specific programs of intervention. The study themes, objectives, selected-findings, major recommendations, and utilization of the YEP OR studies are described overleaf. ${ }^{2}$

2 More detailed information about the studies can be obtained from the Health Research Unit, Ministry of Health, Gaborone, Botswana or the Africa OR/TA Project II. 


\section{"Assessing the Coverage and Adequacy of Services Provided by AMMB to Care Givers of AIDS/HIV Positive Youth"}

\section{(Association of Medical Missionaries in Botswana .}

\section{Study Objectives:}

The ultimate objective of the study was to ensure that AMMB to AIDS prevention, control and care activities, including the home care services for people with AIDS, respond adequately to the needs of the young. This exploratory study identified:

1) The proportion of care givers receiving support from AMMB;

2) Socio-cultual, economic, and religious factors influencing care givers in providing care to youth with HIV/AIDS;

3) Positive and negative attitudes of care givers; and

4) The quality of support services rendered by health workers to care givers and youth with HIV/AIDS.

The results will be used in strengthening AMMB's home based care program and developing similar programs within other NG0s and government.

\section{Selected Findings:}

Sixty-eight care givers were interviewed in three sites. Care givers were predominantly close female relatives of the affected youth and had little education and were either unemployed or low wage earners. All except two care givers said they could not cope with home care if the health of the patient deteriorated and only two care givers were protecting themselves when caring for the patient. Care givers were not regularly visited health workers, therefore, compromising the quality of care.

\section{Major Recommendations:}

- The AMMB AIDS registers need to be updated and made use of in identifying who needs counseling services and home visits.

- Counseling services need to be strengthened to provide better information about the support services available and how infection to care givers can be minimized.

- Health education on HIV/AIDS and home care should target the elderly who are the primary care givers.

- There is a need to strengthen the support system for caring for youth with at the institutional, church, and family level.

\section{Actions:}

A proposal to introduce a hospice in one of the AMMB sites was reviewed and approved.

The AMMB approved specific recommendations to streamline activities and strengthen its home care program. 


\section{"Accessibility, Availability and Use of Condoms among Youth" (Botswana Scouts Association and Botswana Youth Center)}

\section{Study Objectives:}

A descriptive cross-sectional study was conducted by members of the Botswana Scouts Association and the Botswana Youth Centre to determine the attitudes, knowledge and practice of youth (age 13-30) on sexual behaviors, STD/HIV/AIDS, and teenage pregnancy. The specific objectives of the study were:

1) To determine the proportion of sexually active youth and the characteristics, sexual behaviors and condom use of sexually active youth;

2) To assess the attitudes and level of knowledge of the youth about sexual behavior, STD/HIV/AIDS, and pregnancy; and

3) To make relevant recommendations regarding youth sexual behavior.

\section{Selected Findings:}

A self-administered questionnaire was used to interview youth (boys and girls) in the Scouts movement in selected secondary schools in selected major villages and towns. Of the 577 youth who responded to the questionnaire, 37\% reported to have had sex, mainly with a regular partner. Similar percentages of males and females reported they were sexually active. The proportions sexual active increased with increasing age and educational level. Overall condom knowledge was high. Among sexually active youth, $65 \%$ reported that they had used a condom. Of those that had used a condom, $91 \%$ stated they always used condoms. Almost as many females as males reported using condoms and condom use increased with increasing educational level and age. Many of the youth (both sexually active and inactive) gave an ideal age to start having sex which was higher than the current practice. Knowledge regarding STDs/HIV/AIDS was generally good. However, almost one-half of the youth were not willing to have a friend with HIV/AIDS. Youth were less knowledgeable about pregnancy risks.

\section{Major Recommendations:}

- BSA and BYC should develop programs in life skills training to teach youth to be assertive and withstand peer pressure.

- There is need for a clearing house and/or centers for information and referrals young people with particular focus on reproductive health needs of young people

- Reproductive health education should be broadened to include, information on pregnancy, ante-natal care, and child-bearing.

\section{Actions:}

The Botswana Scouts Association started work on the development of a scouts curriculum on youth reproductive health education. 


\section{"Utilisation of Information, Education and Communication Material on HIV/AIDS by Adolescents with Disabilities" (Botswana Red Cross Society and Population Services International)}

\section{Study Objective:}

The ultimate objective was to ensure that youth-targeted IEC materials on AIDS are available to disabled youth. The specific objectives of the study were to determine the: 1) availability of, 2) access to and 3) use of IEC materials by youth with disabilities.

\section{Selected Findings:}

Disabled youth aged 15-29 and service providers in three sites were interviewed. The youth were also shown IEC materials and their reactions observed. The study established that very few of the youth had access to IEC materials on AIDS. The most common IEC materials were posters, but only a minority of the respondents understood their message. The type of disability was associated with whether respondents had access to and could utilize materials; those with difficulty moving were more likely to have seen IEC materials related to AIDS than youth with other kinds of disabilities such as difficulty beaming, communicating, or ill-defined disabilities.

\section{Major Recommendations:}

- Family Welfare Educators should be attached to the NGO delivering rehabilitation services.

- The Ministry of Health in conjunction with NG0s should conduct workshops for people with disabilities regarding HIV/AIDS awareness and the development of appropriate HIV/AIDS IEC materials.

- Family Welfare Educators should be trained in special communication skills to cater for the blind and the dumb.

- PSI should extend their peer education and condom demonstrations to youth with disabilities.

\section{Actions:}

The Botswana Red Cross Society (BRCS), approved specific recommendations to address factors which inhibited optimal availability, suitability and accessibility of IEC materials on HIV/AIDS to youth with disabilities. 


\section{"Effectiveness of Peer Education Training Programs in Gaborone (BOFWA, YWCA, and BOCONGO)}

\section{Study Objectives:}

The ultimate objective was to offer effective peer education to empower youth to make informed decisions and choices on their sexuality The study investigated the extent to which BOFWA/YWCA peer education programs have been effective in preparing peer educators to adequately carry out their tasks to educate youth on reproductive health issues.

\section{Selected Findings:}

Seventy-seven peer educators trained in 1994 and 1995 were interviewed. The majority of the peer educators interviewed were between 17 and 20 years old, $45 \%$ were males and $55 \%$ were females. The peer educators were most satisfied with time allocated during training and the resources persons for the topics of condom use, contraceptives, alcohol and drug abuse and adolescent sexuality. However, these were not the tasks most commonly performed by peer educators. The most common activities were counseling, recruitment, and outreach. Moreover, the peer educators interviewed felt that the training did not adequately prepare them to handle critical situations in their day to day operations. The results also showed that there were inconsistencies in the training programs of BOFWA and YWCA.

\section{Major Recommendations:}

- More emphasis should be put on those aspects of the training that will prepare peer educators to effectively organize their peers, e.g. communications, group dynamics, recruitment, and outreach,

- There is a need to standardize the training curriculum. The two organizations need to increase support and follow-up once the peer educators have been trained.

\section{Actions:}

The Botswana Family Welfare Association (BOFWA) adopted specific recommendations of the operations research project to strengthen its teen peer education training program by developing refresher course for peer educators for 1997. The curriculum for this course addressed training needs revealed in the operations research study.

BOFWA used the research skills acquired through this study to evaluate and re-introduce a Family Life Education training program for primary teachers which had been discontinued. 


\section{LESSONS LEARNED ABOUT NGO STRENGTHENING}

In their end-of-project review ${ }^{3}$ which included debriefings with many of the participating NG0s, the project management team identified specific aspects of the project design as well as different characteristics of the NG0s which contributed to the success of the project. The team also noted hurdles experienced in the project implementation. These success and shortcomings are summarized below.

\section{Design factors which contributed to the success of the project}

- Early and continued close collaboration between the Africa ORITA Project II and local professional institutions. Early collaboration nurtured commitment and ownership and allowed collaborators to gauge their capabilities and appropriate inputs, including human resources, in relation to the project requirements before getting started. The BNPC provided an esteemed, modem institution with access to a wide range of consultants on various aspects of management as well as well-equipped classrooms and catering and boarding accommodation on the premises. Similarly, through the collaboration with the HRU the project was able to access the university consultants who normally collaborate with HRU. Another valuable outcome of collaborating with local institutions was that it provided the opportunity for the NG0s to establish and maintain long term relationships with these resources after the end of the project.

- A full-time Project Coordinator and a local coordinating office. The project coordinator monitored the daily proceedings of the project, ensured the integration of its various elements, assisted with facilitation during training where necessary, provided continuity as various BNPC consultants and NGO participants joined the project, and maintained close communication with Africa OR/TA staff. The local office with an experienced secretary, vehicle, computers and other office equipment was a valuable resource to the NG0s who often lacked these types of support.

3 The full report on the project titled "The Youth Empowerment Project (YEP) - Botswana October 1995 September 1996: An Analysis Of The Project Design And Lessons Learned," prepared by the project coordinator Mercy Rapelesega Montsi (January 1997) is available upon request from the Africa OR/TA Project 11. 
- The creation of a forum for NG0s to share experiences. A number of NG0s had the impression that their problems were unique and almost insurmountable and initially believed that they could not be tackled through the short YEP workshops. This view changed when common concerns and problems were identified and addressed. While this did not necessarily solve the problems, it often brought the magnitude of the problems into perspective. Moreover, through the networking offered by the project, NG0s identified or confirmed areas of common interest and opportunities for collaboration.

- An emphasis on dissemination within the participating NG0s of the training experience. As an integral part of the management training, NGO staff and management discussed staff needs and management constraints, often for the first time, and considered how the tools and approaches taught in the workshops might be applied. Gains in networking were even experienced within the individual NG0s when several staff from the same organization were sent for training and came back "speaking the same language" of management or research.

\section{The Level Of Success Of The Project Within Each NGO Was Influenced By:}

- the absorptive capacity of the NG0s which was directly related to the number of staff on the ground, additional work demands, and academic backgrounds (particularly for those participating in the research component);

- the readiness of senior management for change and their willingness to re-prioritize their work plans and activities to incorporate the YEP objectives and activities within the available project time, beyond just the release of staff to attend workshops; and

- the extent to which management took deliberate steps to select and apply a particular management system. This facilitated exploitation of all its human, financial, and other material and structural resources, especially the deployment of the volunteer human resources which formed an important component of all the YEP NGO personnel. 


\section{Main Constraints}

- The major weakness was the fact that important follow-up activities could not be undertaken due to the shortened time frame. This might potentially weaken the impact on sustained organizational behavior change. Although participants gained substantial theoretical knowledge on management practice through the workshops, not enough time was available to allow for practical exercises and the effective completion of the training objectives through application of the skills and approaches discussed in the classroom. This was especially difficult because of the diverse backgrounds of participants and sometimes unique problems of the different NG0s. Key recommendations and activities resulting from the operations research studies and developed during the technical assistance phase of the management training component were approved and agreed upon with the respective NGO management late in the project. This meant that the project did not have the opportunity to support or monitor their effective implementation. The shortened project time also meant that the project could not complete some of the critical activities such as the development of strategic plans which were initiated during the TA phase of the project or other activities which were initiated in response to the operations research findings.

- Because of under-staffing and the volunteer, top-heavy management structure of most NG0s, the management cadre was under-represented in the YEP training activities. Often NG0s are freer of red tape than governmental organizations and therefore can innovate or introduce new activities easily and quickly. The experience with the YEP showed that while this may be true to an extent, YEP NG0s were run primarily through committees of volunteers who are often difficult to convene at short notice and who may not even attend scheduled meetings regularly because of commitments in their regular jobs. Obtaining clearance for an NGO to undertake long term commitments can be a tedious process unless the NGO had a relatively high-powered full-time executive secretary. Also it was preferable but not usually possible that senior management be involved in many of the activities both to help create an enabling environment for the service personnel who were receiving the YEP training as well as to empower those managers with the knowledge and skills which were being imparted thorough workshops. The under-representation of senior management made it difficult for some NG0s to take best advantage of YEP inputs. 


\section{CONCLUSIONS AND RECOMMENDATIONS}

The project was highly effective in training a number of NGO management and service personnel in basic management skills, including the use of operations research. The project also succeeded in orientating and raising awareness among NGO management about the need and how to systematically identify and address the critical factors for effective organizational change and performance management. The increasing number of participants at workshops; their positive evaluation at the end of workshops; and their presentations at the final dissemination workshop at the end of the project during which each NGO reported to have applied at least some aspect of acquired knowledge and skills all indicate that the project was highly welcomed by all the NG0s. Additionally, YEP enabled the participating NG0s to establish a relationship with the BNPC and HRU which are valuable local resources for organizational development and technical assistance for the empowerment of NGO management.

There is abundant evidence of positive changes in the short term. For example, the project raised awareness and appreciation of the need for strategic planning and by the end of the project seven NG0s were developing, reviewing, or taking greater steps to implement strategic plans. Also the participants who participated in the operations research training and studies gained skills and experience in the steps of operations research from problem identification through to mobilizing management to support the use of the research results. Their organizations have already demonstrated their appreciation of the use of operations research as a management tool by implementing changes in the organization of services as a result of the operations research results.

It is too soon to tell what long term effects the project approach and activities will have on the NG0s who participated. The challenge now is to ensure the sustainability of the change achieved and build on the progress of the past year. YEP participants recommend that additional training be provided in the very near future to enable the trained NGO staff more confidently to apply the valuable introductory knowledge and skills acquired and also facilitate transfer of the same to others who did not get this initial exposure. 
- A training of trainers course including training and planning skills.

- A repeat of the strategic management training with appropriate senior management staff, at least for the YEP NG0s who do not have strategic plans, followed by structured and guided technical assistance for each NGO in the development of a strategic plan and a first year operational plan.

- More intensive and more practically oriented training and technical assistance in project proposal writing and resource mobilisation.

- More practically oriented and tailored training and technical assistance in project management and leadership paying special attention to such issues as transparency, accountability, planning skills, budgeting.

- More practically oriented and NGO-specific training and technical assistance in performance management focusing on review and strengthening of NGO organizational structures; development and application of job descriptions/job definitions; and how to motivate, monitor, evaluate, measure and sustain/increase performance.

- A repeat of the, operations research training should be supported to enable NG0s to complete work started through YEP and also to enable NG0s to (i) further strengthen and exploit skills gained from the first training and (ii) draw up a priority reproductive health operations research agenda which can be used to determine operations research areas of common interest.

- In all of the training, efforts should be made to put together participants of comparable educational background.

- NGO management should be encouraged to create opportunities to apply acquired knowledge and skills.

- Both the training schedules for training at classroom level and the technical assistance should be synchronized with the participants' work plans to avoid conflicting demands on the participants. 